CLINICAL STUDY

\title{
Pituitary-independent effect of octreotide on IGF1 generation
}

\author{
Ana Pokrajac, Jan Frystyk ${ }^{1}$, Allan Flyvbjerg ${ }^{1}$ and Peter J Trainer \\ Department of Endocrinology, Christie Hospital, Manchester, M2O 4BX, UK and ${ }^{1}$ Medical Research Laboratories, Clinical Institute and Medical \\ Department M, Diabetes and Endocrinology, Aarhus University Hospital, Aarhus, DK 8200, Denmark \\ (Correspondence should be addressed to A Pokrajac; Email: anapokrajac@yahoo.co.uk)
}

\begin{abstract}
Background: Somatostatin analogues are frequently used for medical treatment of acromegaly. The rationale for their use is based on the inhibition of pituitary GH secretion; however, there is in vitro evidence that octreotide also acts to inhibit hepatic IGF1 generation.

Aim $\mathcal{E}$ design: We studied the pituitary-independent effects of octreotide on IGF1 generation in 11 severely GH-deficient (GHD) humans (age 38, range 23-52; seven males; body mass index $24.7 \pm 3$ $\mathrm{kg} / \mathrm{m}^{2}$; peak-stimulated $\mathrm{GH}<3 \mu \mathrm{g} / \mathrm{l} ; 3 \pm 1$ pituitary hormone deficiencies) on a stable dose of $\mathrm{GH}$ replacement $(0.4 \pm 0.1 \mathrm{mg})$ for at least 6 months. Patients were studied before and after $50 \mu \mathrm{g}$ of s.c. octreotide three times a day for 7 days.

Results: At study entry, all patients had total IGF1 within age- and gender-related reference range (SDS $0.4 \pm 1.0$ ). Octreotide treatment resulted in a significant decrease in total IGF1 (by $18 \%, 208 \pm 89$ vs $173 \pm 62 \mu \mathrm{g} / \mathrm{l}, P=0.04$ ), free IGF1 (by $13 \%, 0.83 \pm 0.36$ vs $0.70 \pm 0.33 \mu \mathrm{g} / \mathrm{l}, P=0.01$ ) and IGFBP3 $(6 \%, 4475 \pm 745$ vs $4209 \pm 912 \mu \mathrm{g} / \mathrm{l}, P=0.02)$. Octreotide suppressed fasting insulin from $8.1 \pm 3.4$ to $6.3 \pm 4.1 \mathrm{mU} / \mathrm{l}(P=0.01)$ and was associated with an increase in fasting glucose from $5.2 \pm 0.9$ to $5.8 \pm 0.9 \mathrm{mmol} / \mathrm{l}(P<0.01)$. IGFBP1 increased by $84 \%$ from $42 \pm 26$ to $95 \pm 52 \mu \mathrm{g} / \mathrm{l}(P=0.04)$. Conclusion: Our study demonstrates that octreotide induces a significant decrease in IGF1 in severely GHD adults on a fixed dose of GH replacement. This is the evidence for a non-pituitary action of octreotide on the GH/IGF1 axis, most likely by antagonising the action of GH on hepatic IGF1 generation and indirectly, by suppressing insulin secretion.
\end{abstract}

European Journal of Endocrinology $160543-548$

\section{Introduction}

Somatostatin (SST) is a widely expressed, multifunctional neuropeptide, which is the primary physiological inhibitor of $\mathrm{GH}$ secretion from the pituitary gland. Its two most biologically active isoforms comprise 14 and 28 amino acids and have a short half-life of approximately 2-3 min. SST acts through a family of five G protein-coupled somatostatin receptors (SSTRs) 1-5 $(1,2)$ distributed in a tissue-specific pattern.

For therapeutic purposes, synthetic somatostatin analogues (SSTAs) with longer half-life and different receptor subtype preferences have been developed. Octreotide, the first synthetic SSTA proven to suppress GH in patients with acromegaly (3), is an octapeptide, which acts as a ligand with very high affinity for SSTR2, intermediate affinity for SSTR 3 and a moderately high affinity for SSTR5 $(1,2)$. GH-secreting pituitary adenomas most frequently express SSTR 2 and SSTR 5 (4-8), and the efficacy of octreotide to decrease GH in patients with acromegaly correlates with the SSTR2 and SSTR 5 expression in pituitary adenomas (4-11).

IGF1 is the main mediator of GH action, with the liver being the source of approximately $80 \%$ of circulating
IGF1 (12). In plasma, IGF1 is bound to a family of specific binding proteins (IGFBP1 to 6) that prolong its half-life to about $16 \mathrm{~h}$ (13) and assist in delivering IGF1 to target tissues $(14,15)$. As GH has a half-life of $15 \mathrm{~min}$ and is released in pulses mainly at night, serum IGF1 offers a more convenient biochemical marker of the $\mathrm{GH}$ action than circulating $\mathrm{GH}$ levels.

There is a log-linear correlation between mean circulating GH levels and IGF1, although various factors that alter the relationship have been described $(16,17)$. Intrinsic and extrinsic oestrogens antagonise the effect of GH on IGF1 generation in healthy subjects (18), patients with GH deficiency (19) and acromegaly $(20,21)$. Conversely, obesity increases GH sensitivity (22-24), a finding that may be at least partially explained by elevated insulin levels (25).

It has been suggested that, in patients with acromegaly, octreotide treatment reduces circulating IGF1 more than anticipated from the suppression of the endogenous GH secretion, and several groups have commented on this phenomenon $(10,26-28)$. These findings suggest that octreotide action is not confined to the suppression of GH secretion, but that it may also have a direct effect on IGF 1 generation. This notion is 
supported by studies in animals and in vitro. In hypophysectomised, GH-deficient (GHD) rats, octreotide reduced recombinant GH-stimulated mean serum IGF1 concentration by $26-60 \%(29,30)$. No consistent changes were found in serum insulin, excluding it as a potential mediator of the octreotide-induced IGF1 reduction. In vitro studies in cultured rat hepatocytes demonstrated that octreotide reduces GH-induced IGF1 mRNA expression and peptide $(30,31)$.

We designed this study to test the hypothesis that in humans, octreotide lowers serum IGF1 not only by inhibiting $\mathrm{GH}$ secretion, but also by antagonising the ability of GH to stimulate IGF1 synthesis.

\section{Patients and methods}

\section{Patients}

Eleven GHD patients (median age 38 years, range 23-52; seven males, body mass index $24.7 \pm 3 \mathrm{~kg} / \mathrm{m}^{2}$; $3 \pm 1$ pituitary hormone deficiencies) fulfilling the Port Stevens consensus criteria (32) for severe adult GHD (peak-stimulated $\mathrm{GH}$ response $3 \mu \mathrm{g} / \mathrm{l}$ ) were enrolled in the study according to IH GCP (International Harmonization Good Clinical Practice). Patients' characteristics are given in Table 1. All patients were on an optimised, stable dose of hormone replacement therapy including $\mathrm{GH}$ for at least 6 months. Medications remained unaltered throughout the study.

\section{Methods}

After giving written informed consent, patients were asked to take their regular hormone replacement at fixed times. In particular, GH injections were given at the bed time. Patients attended on day 1 fasted from midnight for the baseline assessment. Blood samples were taken for total IGF1, free IGF1, IGFBP1, -2 and -3, insulin and glucose.
The samples were left for 20 min to clot before being centrifuged and aliquotted in duplicates. Serum was frozen at $-80^{\circ} \mathrm{C}$ until assaying. All the assays were performed in a single batch.

Participants were taught to self-inject octreotide subcutaneously (their first injection of $50 \mu \mathrm{g}$ of octreotide was taken under supervision), and were provided with a 7-day drug supply and an injection diary and went on to inject themselves thrice daily at 0800, 1400 and $2200 \mathrm{~h}$. On day 7, they had their morning octreotide injection at $0800 \mathrm{~h}$ and fasted for the reassessment at $0900 \mathrm{~h}$. The blood tests from the baseline were repeated. At the end of the study, patients returned the diaries and remaining injection equipment for evaluation of compliance.

\section{Assays}

Total IGF1 was measured by IRMA using a commercial analyzer (Nichols Institute Diagnostics San Clemente, USA) with intra- and interassay coefficient of variation (CV) $<7.4 \%$ with age- and gender-related reference ranges established by Brabant et al. (33).

Free IGF1 was assessed using centrifuge-forced ultrafiltration followed by immunoassay as described previously (34). The lower detection limit was $0.045 \mu \mathrm{g} / \mathrm{l}$. Intra- and interassay CV averaged at 15-20\%.

IGFBP1 and IGFBP2 were assessed by in-house immunoassays as described previously (35). Intra- and interassay $\mathrm{CV}$ averaged $<5$ and $<16 \%$ respectively, for the IGFBP1 assay, and 5 and $12 \%$ respectively, for the IGFBP2 assay.

IGFBP 3 was measured by a commercial IRMA (DSL Inc. Webster, TX, USA; interassay $\mathrm{CV}<5 \%$ and intra-assay CV $<10 \%$ ).

Insulin was assessed using a commercial electrochemiluminescence immunoassay by Roche Diagnostics GMBH (inter- and intra-assay CV $<2.6 \%$ ), while glucose was measured using an oxidative method Advia $1650 / 1800$ by Bayer Healthcare (CV <6\%).

Table 1 Patients characteristics.

\begin{tabular}{|c|c|c|c|c|c|c|c|}
\hline Sex & Age (years) & BMI $\left(\mathrm{kg} / \mathrm{m}^{2}\right)$ & Diagnosis & Surgery & RT & \# PHD & GH dose $(\mathrm{mg})$ \\
\hline$M$ & 52 & 25.9 & NFPA & $Y$ & $Y$ & 4 & 0.4 \\
\hline $\mathrm{M}$ & 43 & 22.6 & CD & $Y$ & $\mathrm{~N}$ & 4 & 0.4 \\
\hline$M$ & 36 & 25.9 & Astro & $Y$ & $Y$ & 2 & 0.5 \\
\hline $\mathrm{F}$ & 35 & 26.7 & Sheehan's & $\mathrm{N}$ & $\mathrm{N}$ & 2 & 0.3 \\
\hline$M$ & 50 & 23.3 & NPC & $\mathrm{N}$ & $Y$ & 3 & 0.4 \\
\hline $\mathrm{F}$ & 39 & 20.7 & CD & $\mathrm{Y}$ & $Y$ & 5 & 0.4 \\
\hline $\mathrm{M}$ & 39 & 24.4 & CD & $Y$ & $\mathrm{~N}$ & 4 & 0.2 \\
\hline $\mathrm{M}$ & 23 & 29.7 & Pinealoma & $\mathrm{N}$ & $Y$ & 1 & 0.3 \\
\hline $\mathrm{M}$ & 40 & 29.9 & PRL & $\mathrm{Y}$ & $\mathrm{Y}$ & 4 & 0.3 \\
\hline $\mathrm{F}$ & 29 & 22.5 & $\mathrm{IGHD}+\mathrm{GnD}$ & $\mathrm{N}$ & $\mathrm{N}$ & 2 & 0.5 \\
\hline
\end{tabular}

RT, radiotherapy; \# PHD, number of pituitary hormone deficiencies; NFPA, non-functioning pituitary adenoma; CD, Cushing's disease (cured); Astro, astrocytoma; NPC, nasopharingeal carcinoma (cured); Lymph, lymphoma; PRL, prolactinoma (cured); IGHD+GnD, idiopathic GH deficiency and gonadotrophin deficiency. 


\section{Statistical analysis}

The data had Gaussian distribution at baseline when assessed by Kolmogorov-Smirnov test $(P>0.01)$ and consequently results are presented as means \pm s.D. The paired $t$-test was used for comparison of pre- and postintervention results with statistical significance being defined as $P<0.05$.

\section{Results}

All patients were on a stable, fixed dose of GH (mean dose $0.4 \pm 0.1 \mathrm{mg}$ ) and had a total IGF1 within age- and gender-related reference range, as defined by Brabant et al. (33). With octreotide, total IGF1 fell by an average of $18 \%$, from $208 \pm 89$ to $173 \pm 62 \mu \mathrm{g} / \mathrm{l} \quad(P=0.04)$, resulting in total IGF1 levels below the reference ranges in 2 out of 11 patients (Fig. 1).

At baseline, there was a sevenfold variation in individual free IGF1 results (0.189-1.149 $\mathrm{gg} / \mathrm{l})$. Octreotide decreased free IGF1 by an average of $13 \%$ $(0.83 \pm 0.36$ vs $0.70 \pm 0.33 \mu \mathrm{g} / \mathrm{l}, P=0.01$; Fig. 2$)$.

At the study entry, IGFBP 3 was within the normal range in all patients $(4475 \pm 745 \mu \mathrm{g} / \mathrm{l})$. Octreotide treatment reduced IGFBP 3 by $6 \%$ to $4209 \pm 917 \mu \mathrm{g} / \mathrm{l}$ $(P=0.02$, Fig. 3), which remained within reference range.

Octreotide induced a decrease in fasting insulin of $26 \%$ from $8.1 \pm 3.2$ to $6.3 \pm 4.1 \mathrm{mU} / \mathrm{l}, P=0.01)$. The decrease in fasting insulin was reflected by an increase in fasting glucose of $11 \%$, from $5.2 \pm 0.9$ to $5.8 \pm 0.9 \mathrm{mmol} / \mathrm{l}$ $(P<0.01$; Fig. 4).

IGFBP 1 increased significantly $(+84 \%)$ with octreotide from $42 \pm 26$ to $95 \pm 52 \mu \mathrm{g} / \mathrm{l}(P=0.04$; Fig. 5), while IGFBP2 did not change $(120 \pm 44$ vs $133 \pm 90 \mu \mathrm{g} / \mathrm{l}$, $P=0.09$ ).

\section{Discussion}

Our study demonstrates that the addition of octreotide to a fixed dose of GH replacement therapy in adults with severe GHD causes a decrease in total and free IGF1 as well as IGFBP3, but an increase in IGFBP1. These

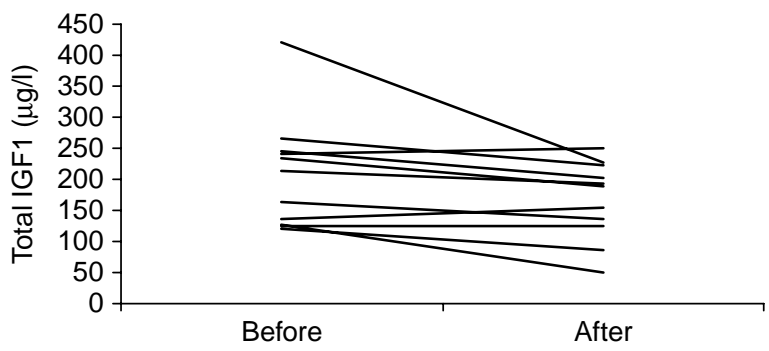

Figure 1 Octreotide reduced total IGF1 by $18 \%$ from $208 \pm 89 \mu \mathrm{g} / \mathrm{l}$, SDS $0.5 \pm 1$ to $173 \pm 62 \mu \mathrm{g} / \mathrm{l}(P=0.04)$, resulting in IGF1 levels below the reference ranges in 2 out of 11 patients.

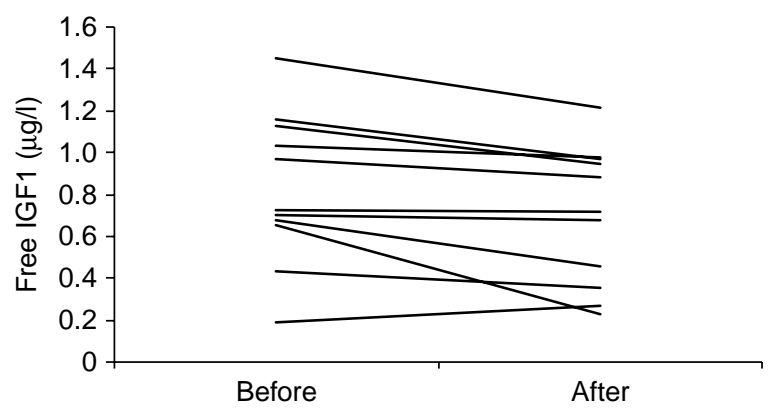

Figure 2 Octreotide decreased free IGF1 by an average of $13 \%$ $(0.830 \pm 0.359$ vs $0.699 \pm 0.332 \mu \mathrm{g} / \mathrm{l}, P=0.01)$.

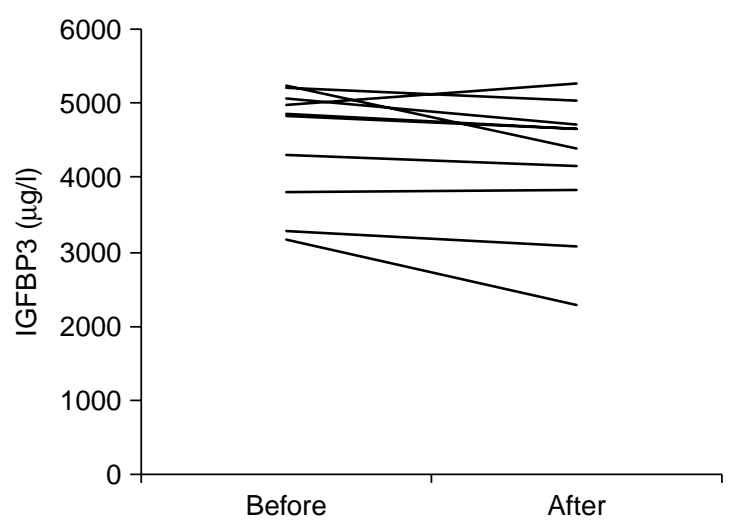

Figure 3 Octreotide reduced IGFBP3 by $6 \%$, from $4475 \pm 745$ to $4209 \pm 917 \mu \mathrm{g} / \mathrm{l}(P=0.02)$.

findings support the hypothesis that octreotide acts to inhibit GH action, as well as $\mathrm{GH}$ secretion.

Our findings are consistent with and extend those of Laursen et al. (36), who studied six GHD patients on recombinant human $\mathrm{GH}$ with and without the addition of octreotide and found a significant decrease in total IGF1 and an increase in IGFBP1 following combination therapy. The study by Laursen et al. failed to document a significant change in free IGF1, while we showed a significant reduction in free IGF1 with octreotide, supporting the total IGF1 results.

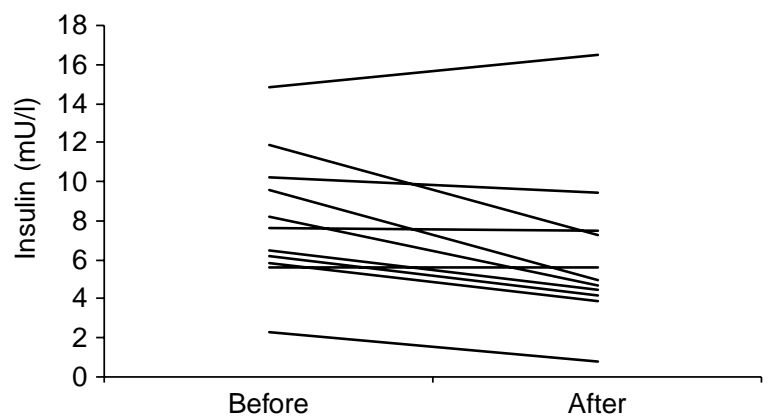

Figure 4 Octreotide reduced fasting insulin by $26 \%$ from $8.1 \pm 3.2$ to $6.3 \pm 4.1 \mathrm{mU} / \mathrm{l}, P=0.01)$. 


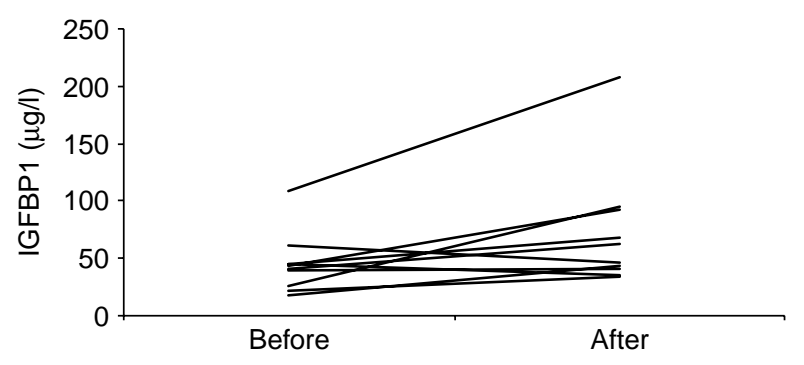

Figure 5 As a consequence of insulin reduction caused by octreotide, IGFBP1 increased significantly $(+84 \%)$ from $42 \pm 26$ to $95 \pm 52 \mu \mathrm{g} / \mathrm{l}(P=0.04)$.

A decrease in total IGF1 may be partially explained by the decrease in IGFBP 3 , as $70-80 \%$ of circulating IGF 1 is bound in a ternary complex with IGFBP 3 and the acidlabile subunit. IGFBP3 is produced in hepatic Kupffer cells rather than hepatocytes, under the control of circulating GH (Rajaram et al. 1997), and although it is not known which, if any, SSTRs are expressed by Kupffer cells, the decrease in IGFBP3 indicates that the octreotide inhibition of the $\mathrm{GH}$ action is not confined to hepatocytes.

Alternatively, unbound IGFBP 3 is known to be rapidly cleared from plasma and, therefore, the octreotideinduced decrease in IGF1 and parallel reduction in ternary complex formation could leave a greater proportion of IGFBP 3 unbound and liable to rapid clearance $(37,38)$.

The decrease in free IGF 1 in our study suggests that the effect of octreotide on total IGF1 cannot be explained solely by a reduction in circulating levels of its most abundant binding protein IGFBP3. Free IGF1 is believed to reflect the biologically relevant, unbound fraction of IGF1, but it is difficult to measure. The method used here is specifically designed to avoid inducing dissociation of loosely bound IGF1, particularly those bound to IGFBP1 (39). The decrease in free IGF1 implies a true reduction in IGF1, not an artefact secondary to IGFBP changes.

There are two, not mutually exclusive, possible mechanisms to explain the reduction in IGF1.

As described above $(30,31)$, in vitro studies have shown a direct, octreotide-induced inhibition of hepatic IGF1 generation. Murray et al. (40) demonstrated the expression of SSTR 2 and SSTR 3 on rat hepatocytes and a cross-talk between octreotide-activated SSTR 2 and 3 and GH-activated GH receptor (GHR) pathways, by dephosphorylating the GHR-linked second messenger STAT 5b. To date, the expression of SSTRs on the human liver has to be documented, but it is presumed to be similar to that in rodents. Another example of antagonism of $\mathrm{GH}$ action induced by interruption of intracellular second messenger pathway has been described with oestrogen. Leung et al. demonstrated that oestradiol via the oestrogen receptor $\alpha$ increased the expression of SOCS2, which is a negative regulator of a second messenger STAT5b involved in IGF1 gene transcription (41).
A second possible mechanism to account for the decrease in total and free IGF1 could be an indirect effect related to the inhibition of insulin secretion by octreotide.

In our study, octreotide suppressed mean fasting serum insulin levels by $26 \%$. Plasma insulin and IGFBP1 are inversely correlated $(42,43)$; thus, in our study, the decrease in mean fasting insulin was associated with an increase in circulating IGFBP1 of $84 \%$. Furthermore, there appears to be a direct stimulatory effect of SSTAs on IGFBP1 generation (44).

Under physiological conditions, approximately $10 \%$ of circulating IGF1 is bound to IGFBP1 (45); thus, an increase in IGFBP1 could contribute to the decrease in free IGF1, but does not explain the decrease in total plasma IGF1.

Leung et al. used a human hepatoma cell model to study the interaction between $\mathrm{GH}$ and insulin receptor pathways and found that insulin, at concentrations comparable with those in our study increased the number of GHR on the cell surface and enhanced the GH-induced intracellular signalling via JAK2 pathway.

This notion of insulin levels and positive regulation of hepatic GHR number and function may explain the increase in GH sensitivity seen in obesity (24).

The portal blood supply of the liver means that it is particularly sensitive to changes in the insulin secretion, and the changes measured in peripheral plasma insulin may not fully reflect the changes in the portal circulation. Pancreatic insulin secretion in humans is predominately regulated by SST through SSTR 2 and, to a lesser extent, SSTR1 and 5 (46). SSTAs such as octreotide have low affinity for SR 5 in comparison with the new SSTA SOM230 (47, 48); hence, any insulin-related reduction in IGF1 levels may be greater with such analogues, but, if accompanied by deterioration in the glucose tolerance, would be metabolically unacceptable.

An alternative interpretation of the data generated by this study is that octreotide inhibited residual endogenous GH secretion in our patients. This seems unlikely, as all our patients had severe GHD and were on long-term (>6 months) GH replacement that should have suppressed any residual intrinsic GH secretion.

This study provides evidence for an extra-pituitary effect of octreotide on IGF1 generation in humans, which is most likely a result of a direct GH-antagonising effect of octreotide on the liver of other organs, and an indirect effect via suppression of the insulin secretion. It is intriguing to speculate that this peripheral action of octreotide may be contributing to the successful use of octreotide with GHR antagonist in patients with acromegaly (49).

These findings are relevant to the treatment of acromegaly and its monitoring, and particularly interesting in the context of newer SSTAs with a different affinity for the various SRs. 


\section{Declaration of interest}

The authors declare that there is no conflict of interest that could be perceived as prejudicing the impartiality of the research reported.

\section{Funding}

This study was supported by Novartis Pharmaceuticals unrestricted research grant and octreotide supply and Novo Nordisk A/S recombinant GH supply. J F and A F were supported by the Danish Research Council for Health and Disease.

\section{Acknowledgements}

We are grateful to our research nurse Margaret Roberts for helping out with the practical aspects of the study and to technician Kirsten Nyborg for helping with the IGF analyses.

\section{References}

1 Reisine T \& Bell GI. Molecular biology of somatostatin receptors. Endocrine Reviews 199516 427-442.

2 Hoyer D, Bell GI, Berelowitz M, Epelbaum J, Feniuk W, Humphrey PP, O'Carroll AM, Patel YC, Schonbrunn A \& Taylor JE. Classification and nomenclature of somatostatin receptors. Trends in Pharmacological Sciences 199516 86-88.

3 Plewe G, Beyer J, Krause U, Neufeld M \& Del PE. Long-acting and selective suppression of growth hormone secretion by somatostatin analogue SMS 201-995 in acromegaly. Lancet 19842 $782-784$.

4 Greenman Y \& Melmed S. Expression of three somatostatin receptor subtypes in pituitary adenomas: evidence for preferential SSTR 5 expression in the mammosomatotroph lineage. Journal of Clinical Endocrinology and Metabolism 199479 724-729.

5 Greenman Y \& Melmed S. Heterogeneous expression of two somatostatin receptor subtypes in pituitary tumors. Journal of Clinical Endocrinology and Metabolism 199478 398-403.

6 Miller GM, Alexander JM, Bikkal HA, Katznelson L, Zervas NT \& Klibanski A. Somatostatin receptor subtype gene expression in pituitary adenomas. Journal of Clinical Endocrinology and Metabolism 199580 1386-1392.

7 Panetta R \& Patel YC. Expression of mRNA for all five human somatostatin receptors (hSSTR1-5) in pituitary tumors. Life Sciences $1995 \mathbf{5 6} 333-342$.

8 Shimon I. Somatostatin receptors in pituitary and development of somatostatin receptor subtype-selective analogs. Endocrine 2003 $20265-269$.

9 Ikuyama S, Nawata H, Kato K, Ibayashi H \& Nakagaki H. Plasma growth hormone responses to somatostatin (SRIH) and SRIH receptors in pituitary adenomas in acromegalic patients. Journal of Clinical Endocrinology and Metabolism 198662 729-733.

10 Reubi JC \& Landolt AM. The growth hormone responses to octreotide in acromegaly correlate with adenoma somatostatin receptor status. Journal of Clinical Endocrinology and Metabolism $198968844-850$.

11 Takei M, Suzuki M, Kajiya H, Ishii Y, Tahara S, Miyakoshi T, Egashira N, Takekoshi S, Sanno N, Teramoto A \& Osamura RY. Immunohistochemical detection of somatostatin receptor (SSTR) subtypes $2 \mathrm{~A}$ and 5 in pituitary adenoma from acromegalic patients: good correlation with preoperative response to octreotide. Endocrine Pathology $2007 \mathbf{1 8} 208-216$.

12 Yakar S, Liu JL, Stannard B, Butler A, Accili D, Sauer B \& LeRoith D. Normal growth and development in the absence of hepatic insulin-like growth factor I. PNAS 199996 7324-7329.

13 Guler HP, Zapf J, Schmid C \& Froesch ER. Insulin-like growth factors I and II in healthy man. Estimations of half-lives and production rates. Acta Endocrinologica 1989121 753-758.
14 Hwa V, Oh Y \& Rosenfeld RG. The insulin-like growth factorbinding protein (IGFBP) superfamily. Endocrine Reviews 199920 761-787.

15 Firth SM \& Baxter RC. Cellular actions of the insulin-like growth factor binding proteins. Endocrine Reviews 200223 824-854.

16 Bates AS, Evans AJ, Jones P \& Clayton RN. Assessment of GH status in acromegaly using serum growth hormone, serum insulin-like growth factor-1 and urinary growth hormone excretion. Clinical Endocrinology 199542 417-423.

17 Ayuk J, Clayton RN, Holder G, Sheppard MC, Stewart PM \& Bates AS. Growth hormone and pituitary radiotherapy, but not serum insulin-like growth factor-I concentrations, predict excess mortality in patients with acromegaly. Journal of Clinical Endocrinology and Metabolism 200489 1613-1617.

18 Juul A, Bang P, Hertel NT, Main K, Dalgaard P, Jorgensen K, Muller J, Hall K \& Skakkebaek NE. Serum insulin-like growth factor-I in 1030 healthy children, adolescents, and adults: relation to age, sex, stage of puberty, testicular size, and body mass index. Journal of Clinical Endocrinology and Metabolism $1994 \mathbf{7 8}$ 744-752.

19 Burman P, Johansson AG, Siegbahn A, Vessby B \& Karlsson FA. Growth hormone (GH)-deficient men are more responsive to $\mathrm{GH}$ replacement therapy than women. Journal of Clinical Endocrinology and Metabolism 199782 550-555.

20 Parkinson C, Burman P, Messig M \& Trainer PJ. Gender, body weight, disease activity, and previous radiotherapy influence the response to pegvisomant. Journal of Clinical Endocrinology and Metabolism 200792 190-195.

21 Eden EB, Burman P \& Karlsson FA. Men with acromegaly need higher doses of octreotide than women. Clinical Endocrinology 200256 73-77.

22 Svensson J, Johannsson G \& Bengtsson BA. Insulin-like growth factor-I in growth hormone-deficient adults: relationship to population-based normal values, body composition and insulin tolerance test. Clinical Endocrinology 199746 579-586.

23 Colao A, Amato G, Pedroncelli AM, Baldelli R, Grottoli S, Gasco V, Petretta M, Carella C, Pagani G, Tambura G \& Lombardi G. Genderand age-related differences in the endocrine parameters of acromegaly. Journal of Clinical Investigation 200225 532-538.

24 Gleeson HK, Lissett CA \& Shalet SM. Insulin-like growth factor-I response to a single bolus of growth hormone is increased in obesity. Journal of Clinical Endocrinology and Metabolism 200590 1061-1067.

25 Leung KC, Doyle N, Ballesteros M, Waters MJ \& Ho KK. Insulin regulation of human hepatic growth hormone receptors: divergent effects on biosynthesis and surface translocation. Journal of Clinical Endocrinology and Metabolism $2000 \mathbf{8 5}$ $4712-4720$

26 Ouabbe HJ \& Plockinger U. Dose-response study and long term effect of the somatostatin analog octreotide in patients with therapy-resistant acromegaly. Journal of Clinical Endocrinology and Metabolism 198968 873-881.

27 Tauber JP, Babin T, Tauber MT, Vigoni F, Bonafe A, Ducasse M, Harris AG \& Bayard F. Long term effects of continuous subcutaneous infusion of the somatostatin analog octreotide in the treatment of acromegaly. Journal of Clinical Endocrinology and Metabolism 198968 917-924.

28 Pokrajac A, Claridge AG, Shakoor SK \& Trainer PJ. The octreotide test dose is not a reliable predictor of the subsequent response to somatostatin analogue therapy in patients with acromegaly. European Journal of Endocrinology $2006 \mathbf{1 5 4} 267-274$.

29 Flyvbjerg A, Jorgensen KD, Marshall SM \& Orskov H. Inhibitory effect of octreotide on growth hormone-induced IGF-I generation and organ growth in hypophysectomized rats. American Journal of Physiology 1991260 E568-E574.

30 Zapf J, Gosteli-Peter M, Weckbecker G, Hunziker EB \& Reinecke M. The somatostatin analog octreotide inhibits GH-stimulated, but not IGF-I-stimulated, bone growth in hypophysectomized rats. Endocrinology $20021432944-2952$. 
31 Serri O, Brazeau P, Kachra Z \& Posner B. Octreotide inhibits insulin-like growth factor-I hepatic gene expression in the hypophysectomized rat: evidence for a direct and indirect mechanism of action. Endocrinology $19921301816-1821$.

32 Growth Hormone Research Society. Consensus guidelines for the diagnosis and treatment of adults with growth hormone deficiency: summary statement of the Growth Hormone Research Society Workshop on Adult Growth Hormone Deficiency. Journal of Clinical Endocrinology and Metabolism 199883 379-381.

33 Brabant G, von zur MA, Wuster C, Ranke MB, Kratzsch J, Kiess W, Ketelslegers JM, Wilhelmsen L, Hulthen L, Saller B, Mattsson A, Wilde J, Schemer R \& Kann P. Serum insulin-like growth factor I reference values for an automated chemiluminescence immunoassay system: results from a multicenter study. Hormone Research 200360 53-60.

34 Frystyk J, Skjaerbaek C, Dinesen B \& Orskov H. Free insulin-like growth factors (IGF-I and IGF-II) in human serum. FEBS Letters 1994348 185-191.

35 Krassas GE, Pontikides N, Kaltsas T, Dumas A, Frystyk J, Chen JW \& Flyvbjerg A. Free and total insulin-like growth factor (IGF)-I, -II, and IGF binding protein-1, -2 , and -3 serum levels in patients with active thyroid eye disease. Journal of Clinical Endocrinology and Metabolism $2003 \mathbf{8 8} 132-135$.

36 Laursen T, Moller J, Fisker S, Jorgensen JO \& Christiansen JS. Effects of a 7-day continuous infusion of octreotide on circulating levels of growth factors and binding proteins in growth hormone $(\mathrm{GH})$ treated GH-deficient patients. Growth Hormone and IGF Research $19999451-457$.

37 Zapf J, Hauri C, Futo E, Hussain M, Rutishauser J, Maack CA \& Froesch ER. Intravenously injected insulin-like growth factor (IGF) I/IGF binding protein-3 complex exerts insulin-like effects in hypophysectomized, but not in normal rats. Journal of Clinical Investigation $199595179-186$.

38 Firth SM, McDougall F, McLachlan AJ \& Baxter RC. Impaired blockade of insulin-like growth factor I (IGF-I)-induced hypoglycemia by IGF binding protein-3 analog with reduced ternary complex-forming ability. Endocrinology 2002143 1669-1676.

39 Frystyk J, Ivarsen P, Stoving RK, Dall R, Bek T, Hagen C \& Orskov H. Determination of free insulin-like growth factor-I in human serum: comparison of ultrafiltration and direct immunoradiometric assay. Growth Hormone and IGF Research 2001 11 117-127.

40 Murray RD, Kim K, Ren SG, Chelly M, Umehara Y \& Melmed S. Central and peripheral actions of somatostatin on the growth hormone-IGF-I axis. Journal of Clinical Investigation 2004114 349-356.
41 Leung KC, Doyle N, Ballesteros M, Sjogren K, Watts CK, Low TH, Leong GM, Ross RJ \& Ho KK. Estrogen inhibits GH signaling by suppressing GH-induced JAK2 phosphorylation, an effect mediated by SOCS-2. PNAS 2003100 1016-1021.

42 Lee PD, Giudice LC, Conover CA \& Powell DR. Insulin-like growth factor binding protein-1: recent findings and new directions. Proceedings of the Society for Experimental Biology and Medicine 1997216 319-357.

43 Pao CI, Farmer PK, Begovic S, Villafuerte BC, Wu GJ, Robertson DG \& Phillips LS. Regulation of insulin-like growth factor-I (IGF-I) and IGF-binding protein 1 gene transcription by hormones and provision of amino acids in rat hepatocytes. Molecular Endocrinology 19937 1561-1568.

44 Wolthers T, Grofte T, Flyvbjerg A, Frystyk J, Vilstrup H, Orskov H \& Foegh M. Dose-dependent stimulation of insulin-like growth factor-binding protein-1 by lanreotide, a somatostatin analog. Journal of Clinical Endocrinology and Metabolism $1994 \mathbf{7 8}$ 141-144.

45 Rajaram S, Baylink DJ \& Mohan S. Insulin-like growth factorbinding proteins in serum and other biological fluids: regulation and functions. Endocrine Reviews 199718 801-831.

46 Strowski MZ \& Blake AD. Function and expression of somatostatin receptors of the endocrine pancreas. Molecular and Cellular Endocrinology $2008 \mathbf{2 8 6} 169-179$.

47 Hofland LJ, van der HJ, Feelders R, van der Lely AJ, de HW \& Lamberts SW. Pre-clinical and clinical experiences with novel somatostatin ligands: advantages, disadvantages and new prospects. Journal of Clinical Investigation 200528 36-42.

48 Hofland LJ, van der HJ, Feelders R, van Aken MO, van Koetsveld PM, Waaijers M, Sprij-Mooij D, Bruns C, Weckbecker G, de Herder WW, Beckers A \& Lamberts SW. The multi-ligand somatostatin analogue SOM230 inhibits ACTH secretion by cultured human corticotroph adenomas via somatostatin receptor type 5. European Journal of Endocrinology 2005152 645-654.

49 Neggers SJ, van Aken MO, Janssen JA, Feelders RA, de Herder WW \& van der Lely AJ. Long-term efficacy and safety of combined treatment of somatostatin analogs and pegvisomant in acromegaly. Journal of Clinical Endocrinology and Metabolism 200792 4598-4601.

Received 19 December 2008

Accepted 6 January 2009 